\title{
Mapping the Food Festivals and Sustainable Capitals: Evidence from Poland
}

\author{
Patrycjusz Zarębski ${ }^{1, *(1)}$ and Dominika Zwęglińska-Gałecka ${ }^{2}$ (i) \\ 1 Department of Economics, Koszalin University of Technology, 75-343 Koszalin, Poland \\ 2 Institute of Rural and Agricultural Development, Polish Academy of Sciences, 00-330 Warsaw, Poland; \\ dzweglinska@irwirpan.waw.pl \\ * Correspondence: patrycjusz.zarebski@tu.koszalin.pl
}

Received: 15 October 2020; Accepted: 5 December 2020; Published: 9 December 2020

check for updates

\begin{abstract}
This study is one of the first attempts to identify and explain the location of food festivals in the context of locally embedded capitals. A multidimensional spatial model was developed and a typology using the k-means method was carried out to evaluate the mapping of 64 food festivals organized in various locations in Poland. With reference to Bourdieu's concept, the economic, social, cultural, symbolic, and tourism capitals rooted in the local environment were examined and compared with the location of festivals. From the theoretical point of view, this study extends the theory of capital to include the new category of tourism capital, which allows better understanding of the economic effects of festivals. It is the missing element of the circular mechanism of capital conversion. Our study shows that food festivals in Poland are held mainly in large cities and their neighboring municipalities rather than in peripheral rural areas. We indicate that the urban areas have a higher level of capitals and sustainability of capitals for food festivals than rural areas. The conducted research shows that the economic effect of food festivals is stronger in locations with high tourism capital. The proposed model is universal and can be used to analyze the impact of various festivals on capital conversion and local development.
\end{abstract}

Keywords: food festival; mapping festivals; food system; embeddedness; sustainable development

\section{Introduction}

The dynamic changes in the world's population result in an increased demand for food, as well as changes in food preferences towards highly processed foods [1]. Since 1970, the daily caloric intake per capita has increased from $2411 \mathrm{kcal}$ to 2789 , i.e., by almost $16 \%$, with a further increase projected to reach $3130 \mathrm{kcl}$ per person by 2050 [2]. The consequence of negative consumption changes is the deteriorating health condition of the population suffering from diseases caused by excessive consumption and poor food quality [3].

The policies of many countries show an increased interest in the sustainable consumption strategy, the aim of which is to shape the demand for food and induce changes in peoples' current nutritional habits [4]. One of the concepts that addresses these problems is a sustainable food system. It assumes that for the needs of present and future generations, food systems should be able to optimize food production and consumption without endangering natural capital resources and ecosystem services [5]. Focusing attention only on agricultural production is insufficient and requires a wider view as well as introducing systemic changes, also in the social system. This means that in the sustainable development policy, apart from the economic and social dimensions, cultural and symbolic aspects should also be taken into account. A multidimensional approach to the problem will allow a better understanding of how food systems have developed and may be further transformed. 
In recent years, rural areas have witnessed a new trend related to the organization of food festivals, which, using old traditions, become an opportunity for get-togethers and spending free time by both local communities and tourists. According to many scientific and political circles, food festivals can become an important ally in the implementation of health policy and sustainable development of rural areas [6-8]. They also contribute to the revitalization of cultural traditions, especially those related to food and historical and cultural heritage [9]. They fulfill a symbolic and bond-forming function for residents, non-governmental organizations, and others. The unique, multifaceted qualities of food festivals are more and more often appreciated. Festivals give tourists the opportunity to discover local uniqueness [10], provide a variety of cultural experiences [11], and are an opportunity to participate in characteristic collective experiences [12]. They create a unique platform on which activities in three areas occur, i.e., social, economic, and natural, which together form the key components of sustainable development. It is believed that this type of activity triggered by the organization of festivals is a carrier of favorable changes in the local economy in terms of job creation and local income [13-16], as well as entrepreneurship [17]. Furthermore, both large cities and towns perceive the organization of festivals as an opportunity to create additional value for their inhabitants, who contribute to their budgets in the form of local taxes. It may result in the pressure of local authorities on the development of local heritage and resources, aestheticization of the local environment, the emergence of new institutions, and the diversification of available services. As a result, these changes may positively affect the inhabitants and their quality of life. They can also stimulate inhabitants' entrepreneurship by motivating them to take their own initiatives. Festivals are also regarded as contributors to pleasurable hedonism, as well as to the social and cultural cohesion of communities; they bring citizens together as visitors and organizers and they are often appreciated for their playful, integrative potential [18].

By organizing events, local authorities want to improve their image and profile, as well as be recognized by local communities $[19,20]$. Festivals can affect rural areas through key groups involved in their organizations and the participation of organizers, entrepreneurs, farmers, exhibitors, visitors, and residents [21]. Food festivals convey the idea of healthy eating habits and promote local agricultural products in the context of sustainable development. Rifkin [22] believes that food, more than any other single experience, brings man closer to nature and establishes the most primal relationship of all, that is the one with the environment. Food and its traditional context become something of a bridge that connects human culture with nature.

Often, a controversial issue is the uncertain profitability of festivals, which in certain situations, need involvement and support from local governments $[23,24]$ or external investors. This means that economic capital is important, however as it turns out, it is not the only important condition. There is a clear gap in the literature on festivals regarding research on the remaining social, cultural, symbolic, and tourism capital, which are equally important in the festival organization process. It is necessary to analyze the phenomenon in the context of its embedding in local environments, while taking into account its complex relationships and processes that can be applied to well-known concepts of sciences, such as the theory of capital [25] and embeddedness [26]. The aim of the article is to identify and explain the location of food festivals in the context of locally embedded capitals.

Research on the resources needed to initiate and hold festivals can be based on the theoretical framework of Bourdieu's capital theory, and explore the role of economic, cultural, social, and symbolic capitals in the festival design process. This will allow assessing the current locations of festivals and their conditions. In particular, it is possible to explore the ways of using particular forms of capital, their combinations, mutual interactions, and substitutability, especially in relation to financial capital. Their combination and use can help explain the determinants of the processes responsible for the survival and success of many festivals. While previous research has shown that financial resources and social networks are important for the development and organization of festivals $[27,28]$, there is a lack of understanding of the impact of cultural resources such as culinary traditions (local food products), social networks (NGOs), as well as tourism capital (tourist attractiveness of the place). 
The main research question is to what extent different types of capitals explain the spatial distribution of food festivals and influence their success and continuation. Since various forms of capital complement each other, we employ, with references to the literature, a simultaneous analysis of the four forms of capital [29]. We assume that a higher level of capital, in its various forms, is positively related to the location of festivals. Furthermore, in the model of capitals, we propose to introduce a fifth category for festival locations-tourism capital [30], which in our opinion can largely explain the economic effects.

By adopting the Bourdieu approach and consistently considering various forms of capital, this article deepens the discussion of the economic and non-economic determinants of festival location in two ways. First, by taking into account the indicators of different forms of capital, we can assess their individual effects. Secondly, we focus on the component of social, cultural, and symbolic capital, which so far have remained largely unrecognized in research on festivals and include measurement of institutionalized (NGOs, clubs, associations) and embodied (participation in culture, mass events) capitals. From the theoretical point of view, this study also extends the theory of capital to include a new category of tourism capital, which allows a better understanding of the economic effects of festivals and is a missing element of the circular mechanism of capital development in the context of the functioning of festivals.

In this context, the article aims to broaden the knowledge about the role of economic, cultural, social, symbolic, and tourism capitals' sustainability and their impact on the location of food festivals on the example of rural areas and cities in Poland. The general theoretical framework is based on three theories: capital theory [25], embeddedness concept [26], and the theory of sustainable food systems [5]. The research questions we seek to answer are as follows:

- What is the spatial distribution of food festivals in Poland?

- What is the capitals potential of the location festivals in Poland?

- What are the conditions for the locating food festivals in Poland?

- What is the role of tourism capital in the capital conversion process?

The conducted research allowed verifying the following hypotheses:

Hypothesis 1. Food festivals are held mainly in large cities and their neighboring municipalities rather than in peripheral rural areas.

Hypothesis 2. Urban areas have a higher level of capitals and sustainability of capitals of food festivals than rural areas.

Hypothesis 3. The impact of food festivals on capitals conversion is stronger if there is a high tourism capital in the local environment.

\section{Literature Review}

\subsection{Capital Theory}

In theoretical, critical, and methodological terms, the concept of capitals is an excellent tool for multidimensional analysis of social space [31-34]. Pierre Bourdieu [25], when creating the theory of capital, aimed to understand and describe the rules governing the social world of capital. Bourdieu defined capital as sums that particular assets put to productive use. Consequently, capitals are resources that function at a given moment as a social relation of power [35] and which can be regarded as a kind of advantage or gain to maintain or increase the social position (both individual and group) and social prestige. Bourdieu considers economic, cultural, social, and symbolic capital to be the basic capitals.

The first of the capitals indicated by Bourdieu defines the possession of material and financial goods, and divides society into the owners and the non-owners. Economic capital consists of those 
resources that can be immediately and directly monetized and whose institutionalized form is the right to property. The indicators describing this capital are objective in nature-they are measurable, quantitative, easy to identify, and test. Operationalized economic capital consists of financial resources (and their indicators) and other business assets. Issues directly related to economic capital are a relatively exploited field of research and theoretical analysis, however, it should be emphasized that they underlie all other types of capital. This means that economic capital has the ability to influence and transform into social or cultural capital.

The second type is social capital, which describes the relationships, contacts, and ties that enable an individual to operate in the social space and contribute to belonging to various social groups. Social capital is productive, which means that it enables achieving certain goals that would not be possible without it. In classic Bourdieu's approach [25], social capital is strictly individual-its high level means that a person (or another entity, e.g., an enterprise) has a certain number of relationships with other entities, whose knowledge, skills, and experience can be used in a given moment. According to other approaches, social capital is of supra-individual, community character, as well as defines the "quality" of the group, and refers to trust, norms, and relationships that can increase the efficiency of society organization in order to achieve specific interests [36-38]. Succinctly speaking, social capital is the sum of resources of a permanent, more or less institutionalized network of relationships, acquaintances, and mutual recognition. For this reason, this capital is also called network capital. It is linked to economic and cultural capital through social investment strategies that achieve multiple benefits.

The third capital, i.e., cultural capital, is knowledge and skills that an individual acquires in the process of socialization, education, and acculturation. It enables the management and use of the resources of other capitals. It can be described as having transformed into being [39]. Although it depends on economic capital, it is not fully and simply inherited, as well as it requires the work and commitment of the individual. It is complex and consists (de facto) of three capitals: internalized-which includes the knowledge and competences of an individual, objectified-which comprises material goods, and institutionalized-covering the status granted by social and/or state recognition.

In turn, symbolic capital determines the position that an individual occupies in society, which is expressed in their prestige or social recognition. Bourdieu claims that it consists of all the evidence of social recognition as well as ways of being seen and noticed in the social space, which in turn translate into the influence on public opinion and access to information. This type of capital relates to prestige, status, and reputation that can be accumulated to legitimize a business practice [40]. This capital is the aggregate value of individual types of capital that make it up (economic, social, and cultural) and the dynamics of its conversions. The essence of symbolic capital lies in conversion, which means that a capital resource of one type can be transformed into a capital resource of another type. An entity can increase economic capital (e.g., profit) by using and stimulating social (e.g., relational resources) and cultural capital (e.g., knowledge and skills).

From the point of view of the topic under consideration, there can be identified a specific type of capital-tourism capital - that is a determinant of economic capital, and at the same time, uses the resources of other capitals indicated by Bourdieu. The literature emphasizes that the main determinants of tourism development are specific features and elements of the natural environment, as well as manifestations of human activity interesting for tourists [41]. Tourist capital can be determined by tourist attractions such as:

- attributes of the attractiveness of the destination: equipment, accommodation prices, and transport networks [42];

- historic and cultural sites, nightlife, outdoor activities, natural environment and openness, human hospitality [43];

- landscape [44];

- clean and quiet environment, quality of accommodation facilities, family facilities, safety, accessibility, reputation, entertainment, and recreational opportunities [45]; 
- festivals as an element embedded in local ecosystems of sport, culture, and business [18];

- events related to the region's sporting heritage and other smaller sporting events, including mass sporting and recreational events [46].

The literature often emphasizes that the main determinants of the volume of tourism demand are high natural and anthropogenic values [30]. Tourist values play an important role in accommodation facilities located in places with developed tourist functions [32] and facilities that have significant cultural and historical values, monuments, and cultural objects. Tourist values are specific features and elements of the natural environment, as well as manifestations of human activity that are of interest to tourists. Tourist values can have a recreational, sightseeing, and specialist character. The first create specific conditions for the rest, as well as provide regeneration based on elements of the natural environment, such as water (sea, rivers, lakes), clean air, forests, terrain, etc. On the other hand, sightseeing values are of explorative interest to tourists. Among them, there can be distinguished natural values created without human interference or with their little impact (e.g., national and landscape parks), and cultural values or objects of material and non-material culture.

At the individual (micro) level, the existing capitals affect the level and quality of tourism capital, at the meso level, they enable the exchange of resources and innovation, while at the macro level, they affect the development of the tourism sector. In the case of festivals, symbolic capital may manifest in the form of participants' interest in a given event, the number of participants and the willingness to pay for participation in the event. The tourism capital is the key determinant of many elements of the redeployment and development of technical, social, and transport infrastructures, communications technology, as well as the quality of human capital and tourist attractions created by man.

The capital conversion model should take into account, first of all, the elements important from the point of view of the possibility of conversion and generating income, e.g., those that create real investment attractiveness [41]. In the case of tourism, it is related to service infrastructure, technical infrastructure, and the finances of municipalities [47]. These are elements relating to both spatial development and market and administrative conditions in a given area, including the business environment, government policy, and the organization of important events [41,46]. Tourist capital is created as a result of the conversion of the cultural capital of a given place. This means that specific cultural values are used to create local tourist products and tourist infrastructure, including restaurants and accommodation facilities. The tourism industry, in turn, is responsible for converting tourism capital into economic capital. This allows us to complete and close the conversion cycle of all capitals.

\subsection{Concept of Embeddedness}

Among the relatively new concepts in social sciences that researchers refer to is the concept of the embeddedness of the social economy, derived from the works of Mark Granovetter [26,48] and, more broadly, from the so-called new economic sociology [49]. Embeddedness is defined as undertaking economic activities determined by social relations. The concept of social embeddedness states that economic activities are a form of social action. Social and economic reality are closely related, which is why the market should be seen as a special category of social relations and cultural values [50]. Economic activities are not purely rational or structurally determined, but are shaped and constrained by relations between actors and between institutions [51]. In turn, institutions and economic entities are social structures. They arise as a result of the clash of conflicting interests of entities operating in economic life.

According to this concept, economic phenomena not only acquired a social dimension and embedded in culture [52], but also took on a processual character. On an individual basis, according to this concept, a person does not first seek to protect individual interests and possessed material goods, but tries to strengthen his social position, as well as social claims and advantages [53]. There is a clear link between the economy and the social and cultural structure. These structures have a direct impact on economic activities in the market. Granovetter [26] indicates that the social structure, and in particular social networks, play a key role in the flow of information on the market. The credibility 
and quality of information is greater when it comes from people or entities known to a given entity, information from anonymous sources is less valuable. Economic relationships based on frequent contacts, as a rule, lead to the formation of bonds based also on social content, which brings with it the expectation of trust and lack of opportunism. Information transferred within the network carries the content of both positive and negative actions taken by partners-this is how trust is built between them $[37,38]$.

At the micro level, the concept of rooting refers to the use of local resources for the development of a given area, both in the economic, social, and cultural dimensions. Festivals are the tool for this development. They refer to symbols and resources embedded in culture, which are related to both production and consumption activities within local communities [54]. Festivals based on resources and social and cultural capital, if successful, contribute to the achievement of economic effects. Food festivals have their own specificity, which determines a number of activities related to the organization of such events and their subsequent effects. Food festivals are deeply rooted in local ecosystems. This is related to the culinary traditions that are used during festivals as their main value. Their organization contributes to the maintenance and enrichment of the cultural tradition. The main factors that create a unique group of conditions are primarily climatic, historical, social, and cultural factors. These factors are the reasons that they have to be taken into account when planning festivals, and why not every location guarantees the success of their organization.

\subsection{Concept of Sustainable Food System}

Another concept that is important to us from the point of view of the subject of the article is the concept of a sustainable food system. At the beginning, it should be emphasized that the food system includes both consumption and production of food. One of the basic definitions of the food system indicates that it is a chain of human-organized activities related to the production, processing, transport, sale, cooking, and consumption of food, as well as the disposal of waste resulting from such activities [5]. Today, the world food system is characterized by industrialization and concentration, with a few large-scale operators having power over a significant proportion of overall food production. However, with the projected increase in the world's population, the global food system will have to increase its productivity over the next 30 years, drastically reducing its negative impact on the environment. That is why many countries are now taking steps to transform their national food systems in the long term to serve as a benchmark for sustainable competitiveness, human health, and planet protection, and provide livelihoods for all actors in the food chain. The policy of sustainable development, understood as a social-ecological-economic policy ensuring the progress of civilization, is to lead to an integrated solution of economic, social, and environmental problems. Sustainable development, both in the context of food and other areas of human activity, is one of the key challenges faced by societies in the 21 st century $[55,56]$.

Sustainable development of food system is understood as meeting the needs of consumers today and in the future, while minimizing the use of non-renewable resources and the environmental impact [57]. According to the assumptions of the European Commission (2020), a sustainable food system ensures food security and nutrition for all in such a way that the economic, social, and environmental foundations of generating food security and nutrition for future generations are not endangered. Therefore, a sustainable food system should ensure and contribute to all elements of environmental, social, and economic sustainability. It is a system that ensures the safety of consumers, producers, and food, as well as does not burden the environment $[4,5]$.

Today, there are strong links between sustainable development, food, and tourism, which are of interest to academicians and practitioners alike. Food production and consumption are important aspects of the development of sustainable tourism and food systems. In the long run, tourism affects culinary trails, food value chains, and distribution channels [5]. Sustainable food development influences not only modern diets and food systems, but also has an important historical context. Locally distinguishable food can be a tourist attraction and can shape the image of the destination [58]. 
Food festivals that promote local food are associated with many attributes of "localness", including freshness, support for the local economy and small farms, as well as environmental sustainability [41]. They are organized spontaneously, at the local level, usually without the participation of state authorities-as a rule, they are included in larger tourism projects aimed at affirming locality (traditional forms of economy, production, and processing). Food tourism, which includes food festivals, allows tourists to get to know what is authentic in the culinary heritage, production, preparation, and tasting of products and dishes of a given region, without disturbing the symbiosis of society and tourists in this area [58].

\section{Materials and Methods}

\subsection{Conceptual Framework}

In order to analyze the determinants of the location of food festivals in various ecosystems, we applied the conceptual framework of capital theory and sustainable food systems (Figure 1), which were adapted from the selected theoretical framework. In society, cultural capitals, along with economic and social (network) capitals, are key, constructive elements of the theory attempting to describe and explain the mechanism of formation of class structure and the mechanism of its reproduction. It is also important from the point of view of the process of selecting a location for food festivals. A special feature of festivals is their local character and rooting in the local food system. This means that festivals benefit from local cultural, social, symbolic, and economic capitals. These capitals are often a critical mass, without which the organization of festivals would be impossible. Economic capital (ECC), which influences the level of cultural capital (CUC), has the greatest liquidity and is most easily convertible to other types of capital. It is also crucial in creating social (SOC) and symbolic (SYC) capitals. The functions and economic processes of culinary ecosystems are additionally strengthened by the symbolic capital (SYC) and the tourism capital (TUC), which create the supply of event, accommodation, and catering services. Demand from residents and tourists for these services generates income, which in the next cycle, may further strengthen economic and other capitals. In this way, we obtain a circular model of flows and relationships stimulated by food events.

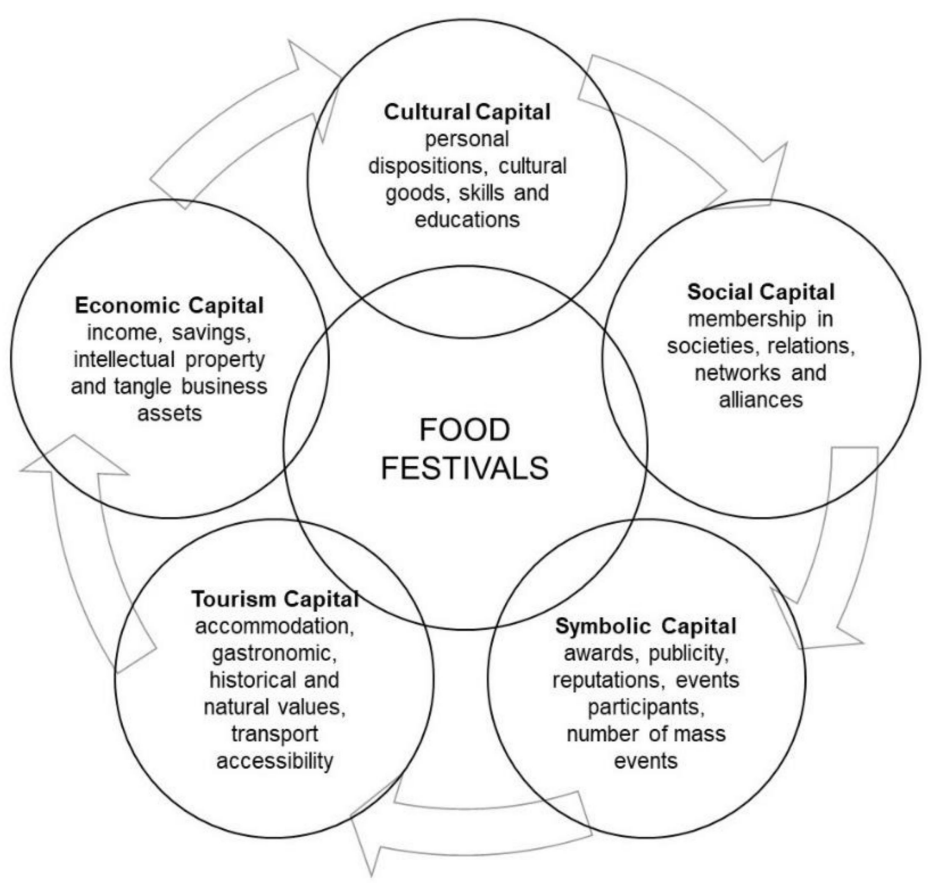

Figure 1. Conceptual framework to analyze relationships between capitals and food festivals. Source: Author's own elaboration. 
Local agricultural considerations such as climate, agricultural land use, and agricultural and culinary traditions influence the ability of food ecosystems to provide local food products and culinary events. For generations, as a result of the circulation of capital, knowledge has been accumulated, the durability of which is conditioned by culture, society, and economy. Maintaining agricultural traditions and food preparation skills is therefore a combination of all capitals. The survival of food systems depends on their sustainability. Actors of sustainable food systems, along with their social and economic relations, also determine the type and level of use of ecosystems, which may result in an unequal distribution of festivals.

In this study, we refer to Bourdieu's capital theory [25], and its four forms [29]. Moreover, in the case of the analysis of the conditions for the location of festivals, we propose to introduce the fifth category of tourism capital [30], which constitutes a significant link between other capitals and influences the growth of economic capital (Figure 1).

Five categories of capitals create a circulation mechanism which, being a dynamic system, strives for sustainable development and sustainability between capitals through the process of capital conversion and their inheritance. In the context of this theoretical framework, we propose a new approach in which the five categories of economic, cultural, social, symbolic, and tourism capitals are equally important and their use is aimed at supporting long-term socio-economic progress, while protecting the environment and sustainable food systems.

The white arrows indicate the links between capitals in the area of the food festival system. In the first place, economic capital influences the level of cultural goods and the durability of keeping tradition. Farms in a good economic condition may maintain their traditions related to food production and pass them on to future generations. Economic success and the generated income counteract marginalization and migration processes of young people from rural to urban areas. On the other hand, the resources of social (network) capital are derived from both previous capitals. Social relations often result from the status, determined by the economic position, and the possessed cultural resources. They are conducive to cooperation and conversion into symbolic capital, i.e., specific features and reputation of a given location that help create festivals. The economic success of festivals depends not only on the income earned by the organizers. Participants of mass events often use tourist infrastructure, accommodation, and catering facilities. It is the demand for these services that constitutes additional local income and supplies local budgets of enterprises and households.

In this study, we first operationalized the potential of the five capitals based on empirical indicators. We conducted analyses of festival locations to quantify spatial patterns and relationships between individual capitals. In order to relate capitals to the level of sustainable development of capitals, we derived a multidimensional indicator based on 15 indicators. By carrying out multi-dimensional analyses of the capital structure, we finally identified and analyzed the spatial consistency and discrepancies between the sustainability of capitals and the location of festivals.

\subsection{Measuring Capitals}

To assess the level of sustainable development of municipalities' capitals in Poland, we used 15 indicators, each representing one of the five capitals: economic, social, cultural, symbolic, and tourism (Table 1). Moreover, these indicators were related to several thematic areas, such as income, unemployment, educational background, education, expenditure on culture, participation of residents in social organizations. The model also takes into account two groups of indicators, not used so far, which describe symbolic capital by the number of participants in mass events and tourism capital represented by the number of accommodation sites, restaurants, and tourism expenses. Taking these capitals into account was necessary due to the aim of the research and the analysis of the phenomenon of food festival location. 
Table 1. Forms of capital and its indicators.

\begin{tabular}{|c|c|c|}
\hline Capital & Indicator & Year \\
\hline \multirow[t]{3}{*}{ Economic } & X1 Real estate tax revenue per capita & 2019 \\
\hline & $\begin{array}{l}\text { X2 Shares in taxes for state budget revenue, personal income tax } \\
\text { per capita }\end{array}$ & 2019 \\
\hline & $\begin{array}{l}\text { X3 Share of the registered unemployed persons in the population in the } \\
\text { working age }\end{array}$ & 2019 \\
\hline \multirow[t]{3}{*}{ Cultural } & $\begin{array}{l}\text { X4 Expenditure of municipalities' budget for culture and national } \\
\text { heritage per } 1000 \text { inhabitants }\end{array}$ & 2017-2019 \\
\hline & $\begin{array}{l}\text { X5 Graduates of courses organized by centers of culture per } \\
1000 \text { inhabitants }\end{array}$ & $2017-2020$ \\
\hline & X6 Share of the population with higher education & 2002 \\
\hline \multirow[t]{3}{*}{ Social (network) } & $\begin{array}{l}\text { X7 Number of foundations, associations, and social organizations per } \\
1000 \text { inhabitants }\end{array}$ & 2019 \\
\hline & X8 Members of groups (clubs/sections) per 1000 inhabitants & 2019 \\
\hline & X9 Members of sports clubs per 1000 inhabitants & 2019 \\
\hline \multirow[t]{3}{*}{ Symbolic } & X10 Number of participants of mass events per $\mathrm{km}^{2}$ & 2017-2019 \\
\hline & X11 Number of participants events-pay entrance per $\mathrm{km}^{2}$ & 2017-2019 \\
\hline & $\mathrm{X} 12$ Number of mass events per $\mathrm{km}^{2}$ & 2017-2019 \\
\hline \multirow[t]{3}{*}{ Tourism } & $\mathrm{X} 13$ Expenditure on tourism per $\mathrm{km}^{2}$ & 2017-2019 \\
\hline & X14 Number of beds per $\mathrm{km}^{2}$ & 2019 \\
\hline & X15 Number of restaurants per $\mathrm{km}^{2}$ & 2019 \\
\hline
\end{tabular}

Source: Author's own elaboration.

Conditions for the location of festivals are a complex phenomenon, and their measurement requires the involvement of various indicators that describe numerous phenomena [30,59]. The difficulty of measuring capital is the translation of theoretical assumptions into measurable empirical indicators.

The theory of capital describes conversions starting from economic capital, which is the cause of the formation of cultural and social capital. The theory has two important features that determine the method of operationalization of its basic components and is dynamic and probabilistic at the same time. Consequently, both concepts are dual in nature and their operationalization is a statistical task. The impact of festivals on the conversion of capitals can be viewed in a narrow and broad sense. The direct beneficiaries of food festivals are agricultural producers and food producers. However, from the point of view of assessing the impact of the organization of festivals in a given location, we are looking for links in a broad sense that include all stakeholders. These include residents (employment), entrepreneurs (income), and local authorities (budget revenues) directly involved in the organization of festivals, as well as stakeholders indirectly benefiting from such events, which include the tourism industry. Therefore, we introduced a new category of tourism capital into the model, which in our opinion, strengthens the economic effect and increases local income. Our attempt to operationalize capital theory and apply general indicators in this case was to take into account all incomes and effects that are achieved in the local economy. The later effect of conversion to cultural and social capital depends on the level of these general incomes. From the point of view of the research problem, it would be advisable to conduct a detailed survey of individual stakeholders of food festivals and evaluate the impact on their income and the impact of income on other cultural and social aspects. Our goal, however, was to present a general model of capital conversion and on its basis assess the location of food festivals. This creates an analysis path from general to specific. The area we adopted to build the capital potential model covers 2477 municipalities in Poland.

To operationalize the individual capital categories for all 2477 municipalities, we used data from public statistics. In the case of economic capital, it should be noted that official statistics do not include data on the incomes of residents at the local level. Therefore, the first two categories are components of budget revenues and directly indicate the own revenues generated by local authorities. However, they indirectly inform about the income earned by local communities (the amount of taxes paid on 
the income earned) and the level of wealth and investment in infrastructure in a given location (real estate tax). In the case of the labor market and employment index, it was not possible to obtain the number of people employed in the local economy from official statistics, therefore we decided to use an index related to the number of unemployed persons in relation to the working age population, being aware of the imperfection of this measure. We assumed that the total information value of these three indicators would allow us to broadly assess the economic capital of the local community.

From the point of view of the theory of capitals, social capital is a network of relationships that is formed in local communities. The relationships of social groups directly related to food and its production play a key role in the organization of food festivals. However, on the other hand, in our opinion, social networks are a complex phenomenon and in the case of their analysis, one should take into account all relations and communication channels that may arise in the local space. For example, in Poland, in rural environments, sports clubs are often the dominant form of integration of local communities. Relationships developed in this way can also be used in the case of food festivals. To assess social capital, we used both the number of foundations, associations, and social organizations, as well as the number of members of groups of 11 thematic groups, such as: the rural housewives' clubs, plastic/technical, dance, music, computing, photography and film, theater, tourism, and sports and recreation, literary, senior/University of the Third Age, film discussion clubs, as well as sports clubs. Indicators allow for indirect measurement of the network of relationships that are formed in local communities. The number of groups shows the frequency of meetings and potential contacts. In turn, the number of participants shows the reach of the network. These two indicators are complemented by the number of members of sports clubs, which is an important platform for communication and meetings both in rural and urban environments.

In accordance with the adopted theoretical assumptions, cultural capital is conditioned by economic capital. This means that the economic resources of a household, together with the existing cultural capital resources, influence the course of the process of learning culture and the level of its school achievements. The inheritance process does not only concern economic goods, but also access to culture through books, paintings, musical instruments, and the possibility of participating in cultural events, including festivals, theater performances, and film screenings. The process of socialization and education is therefore conditioned by access to culture and economic capital. In the process of education and upbringing, the child learns to understand cultural codes, cultural heritage, develops its taste and the need to participate in local cultural events. The measurement of cultural capital refers, on the one hand, to the estimation of what in the process of socialization can be inherited thanks to social origin, and on the other hand, by observing the educational process, e.g., participating in various types of courses and training, as well as completed schools and the level of education. An individual's cultural resources are recognized by examining their way of participating in culture (high or popular) and the manifestations of their individual lifestyle.

Cultural capital in a broad sense is created in local communities on the basis of economic capital. It results from the process of converting earned income into cultural goods. What is important here is the creation of local culture as such, based on local values. One of them is, of course, culinary traditions. The durability of various forms of cultural tradition depends on the involvement of local communities and their wealth. The cultural values of the place represented by the culinary traditions and local products are the most important element in creating the local culture and the key factor justifying the location of food festivals. Our goal is to show the cultural potential. Therefore, the selection of indicators takes into account both the conversions of economic capital in the form of expenditure of municipalities budget for culture and national heritage, as well as the level of population education in the form of graduates of courses organized by centers of culture per 1000 inhabitants between 2017-2020 and share of the population with higher education. In the case of the last indicator, we used data from 2002, because in our opinion, this indicator shows the effect of deferred benefits resulting from education of the inhabitants, both in terms of their potential involvement in cultural life, as well as the process of education and transfer of knowledge to new generations. 
The last two types of capitals are crucial to explaining the development of economic capital. In line with the theory, we assumed that symbolic capital should indicate those features that distinguish a given location and its community. In the case of food festivals, it will be the attractiveness of the place for the organization of festivals in general. An observable effect of this attractiveness is the number of participants broken down into free admission and the number of paying for entry, and the number of organized events. However, in order for symbolic capital to be fully utilized and to be converted into economic capital at a higher level, tourism capital is needed. These are mainly restaurateurs and owners of accommodation facilities who obtain income from the organization of festivals and the tourist attractiveness of the place. The delineation of these two capitals allows, when preparing the typology of municipalities, to indicate those locations that do not fully use this phenomenon. We included the remaining stakeholder groups in tourist capital and symbolic capital.

The values of individual capitals were determined using the algorithm of zero unitarization sums [60], for which appropriate empirical indicators were selected. In the selection of indicators, the assumptions of the capital theory and solutions used in similar studies were taken into account $[59,61]$. In the next step, the ratios were standardized and then grouped, making it possible to obtain synthetic ratios for each capital. Due to the aim of the research, which is to define the relationship between the components of the model and the location of festivals, the same weights of the model indicators were used [62]. The process of aggregation and sustainability assessment included the implementation of the following activities:

- determining capitals;

- selecting empirical features;

- $\quad$ standardizing variables;

- calculating sums of zero unitarization for capitals;

- grouping units of the surveyed population by capital groups and assessment of the sustainability of the indicator structure (k-means classification).

The level of capital was assessed using the method of linear ordering of standardized sums data. The procedure begins with standardizing by normalizing univariate variables according to the following formula:

$$
x_{i j}^{\prime}=\frac{x_{i j}-x_{\min j}}{x_{\operatorname{maxj}}-x_{\min j}} 100
$$

where:

$j$ next feature number,

$i$ next spatial unit number,

$x_{i j}{ }^{\prime} \quad$ normalized feature $j$ in the spatial unit $i$,

$x_{i j} \quad$ value of the feature $j$ in the spatial unit $i$.

If the nature of the variable is different, e.g., destimulants or nominants, the procedure for the replacement for a stimulant should be applied:

$$
x_{i j}{ }^{\prime}=\frac{x_{\max j}-x_{i j}}{x_{\operatorname{maxj}}-x_{\min j}} 100 .
$$

Based on standardized variables, a vector of standardized sums for individual capital is then determined. These are the arithmetic mean values of the standardized features which correspond to individual facilities, where $\mathrm{n}$ is the number of capitals and $\mathrm{m}$ is the number of variables in a given capital dimension, according to the formula:

$$
q_{i}=\frac{1}{m} \sum_{j=1}^{m} x_{i j}{ }^{\prime} .
$$


For easier interpretation, the indicators were grouped into 6 clusters (Table 2), which are components of the model (Table 1). The k-means method, which was also applied to assess sustainable social development, was used for the evaluation of sustainable capitals [63]. The k-means algorithm is a clustering technique widely used in numerous studies to classify input data into k clusters [64-67].

Table 2. Typology of municipalities according to structure of synthetic capital indicators.

\begin{tabular}{|c|c|c|c|c|c|c|c|c|c|c|}
\hline \multirow{3}{*}{ Type } & \multicolumn{5}{|c|}{ Capital } & \multicolumn{5}{|c|}{ Municipalities } \\
\hline & Economic & Cultural & $\begin{array}{c}\text { Social } \\
\text { (Network) }\end{array}$ & Symbolic & Tourism & $\mathbf{u}^{* *}$ & $\mathbf{u}-\mathbf{r}$ & $\mathbf{r}$ & & tal \\
\hline & \multicolumn{5}{|c|}{ Average Value of the Cluster } & \multicolumn{4}{|c|}{$\%$} & $\mathbf{N}$ \\
\hline 1 & $\begin{array}{l}0.233 \\
(-)^{*}\end{array}$ & $\begin{array}{c}0.053 \\
(-)\end{array}$ & $\begin{array}{l}0.001 \\
(\sim \sim)\end{array}$ & $\begin{array}{l}0.092 \\
(\sim \sim)\end{array}$ & $\begin{array}{l}0.003 \\
(\sim \sim)\end{array}$ & 3 & 74 & 23 & 24.7 & 612 \\
\hline 2 & $\begin{array}{c}0.393 \\
(++++)\end{array}$ & $\begin{array}{c}0.152 \\
(++++)\end{array}$ & $\begin{array}{c}0.139 \\
(++++)\end{array}$ & $\begin{array}{l}0.125 \\
(++)\end{array}$ & $\begin{array}{c}0.183 \\
(++++)\end{array}$ & 93 & 3 & 4 & 3.1 & 76 \\
\hline 3 & $\begin{array}{c}0.449 \\
(++++)\end{array}$ & $\begin{array}{c}0.194 \\
(++++)\end{array}$ & $\begin{array}{c}0.688 \\
(++++)\end{array}$ & $\begin{array}{c}0.154 \\
(++++)\end{array}$ & $\begin{array}{c}0.235 \\
(++++)\end{array}$ & 100 & 0 & 0 & 0.2 & 5 \\
\hline 4 & $\begin{array}{l}0.336 \\
(\sim \sim)\end{array}$ & $\begin{array}{l}0.059 \\
(\sim \sim)\end{array}$ & $\begin{array}{l}0.002 \\
(\sim \sim \sim)\end{array}$ & $\begin{array}{c}0.084 \\
(-)\end{array}$ & $\begin{array}{l}0.006 \\
(\sim \sim)\end{array}$ & 5 & 69 & 26 & 37.5 & 929 \\
\hline 5 & $\begin{array}{c}0.396 \\
(++++)\end{array}$ & $\begin{array}{c}0.139 \\
(++++)\end{array}$ & $\begin{array}{l}0.012 \\
(\sim \sim)\end{array}$ & $\begin{array}{l}0.107 \\
(\sim \sim)\end{array}$ & $\begin{array}{l}0.029 \\
(\sim \sim)\end{array}$ & 36 & 39 & 26 & 13.6 & 336 \\
\hline 6 & $\begin{array}{l}0.302 \\
(\sim \sim)\end{array}$ & $\begin{array}{l}0.076 \\
(\sim \sim)\end{array}$ & $\begin{array}{l}0.002 \\
(\sim \sim)\end{array}$ & $\begin{array}{c}0.144 \\
(++++)\end{array}$ & $\begin{array}{l}0.008 \\
(\sim \sim)\end{array}$ & 8 & 60 & 32 & 21.0 & 519 \\
\hline M & 0.314 & 0.075 & 0.009 & 0.103 & 0.014 & & & & & \\
\hline SD & 0.067 & 0.046 & 0.043 & 0.039 & 0.045 & & & & & \\
\hline
\end{tabular}

K-means clustering description: $\mathrm{k}=6$, item $=10$, sum squared error (SSE) $=12.13355174 .{ }^{*}$ symbol description of standardized value of centroids: ++++ very high $(>M+S D),++$ high $(>M+0.4 S D), \sim \sim$ medium $(>M-S D 0.4)$, - low $(>M-S D)$, - very low $(<M-S D)$. ${ }^{* *}$ administrative division of municipalities in Poland: $\mathrm{u}$ urban, $\mathrm{u}-\mathrm{r}$ urban-rural, $r$ rural. Source: Author's own elaboration on the basis of data of the Local Data Bank of the Statistics Poland (the list of data used-see Table 1).

Each type of the municipalities can be described using two parameters of the capital value and sustainability. In order to clarify the structure of each type, the value of capital in a given type was determined and the appropriate symbol assigned to it, which facilitates the interpretation of the obtained results. The value of capital was assessed in relation to the mean $\mathrm{M}$ and standard deviation SD of the entire study population in accordance with the following classification:

$$
\begin{gathered}
M^{\prime}>M+S D \text { very high }(++++), \\
M^{\prime}>M+0.4 S D \text { high }(++), \\
M^{\prime}>M-0.4 S D \text { medium }(\sim \sim), \\
M^{\prime}>M-S D \text { low }(--), \\
M^{\prime}<M-S D \text { very low }(----),
\end{gathered}
$$

where:

$M^{\prime}$-average capital value for a type,

$M$-average capital value for the entire set,

$S D$-standard deviation for the entire set.

In this way, we obtain an assessment matrix of individual capitals. A high level of sustainability of the capitals occurs when obtaining comparable high values of all capitals that differ from each other by only one class. While the unsustainable type occurs in a situation of large disproportion in the assessment of at least one of the capitals in relation to the others (see Table 2). 


\section{Results}

The research results are presented based on the following structure. First, the levels of capitals and their profile according to the adopted administrative units of municipalities were discussed. This provided insight into the level of sustainability of capitals. Then, the obtained results were compared with the locations of food festivals in Poland.

\subsection{The Potential of Capitals and Their Sustainability}

The indicators describing individual capitals were standardized and combined, thus making it possible to obtain a synthetic measure for each capital group. Then, municipalities were grouped into 6 classes using the k-means cluster analysis algorithm (Table 2). For greater readability of the results, the profile control tables present both data on the location of the center of gravity of individual types and figurative symbols of numerical values. Table 2 presents the potential of capital in Poland in terms of structure. The total number of examined administrative units is 2477, including 302 urban municipalities, 642 urban-rural municipalities, and 1533 rural municipalities. The conducted research shows that the biggest type 4 covers about $37 \%$ of municipalities in Poland, mainly of an urban-rural nature. It is also a group of municipalities that presented moderate capital values and a low level of symbolic capital. Type 3 is the smallest group, which includes only 5 cities.

The obtained results of the spatial distribution of the capital typology can be related to the characteristic regions of Poland (Figure 2). Types with relatively low capitals are mainly located in eastern Poland, in contrast to western Poland, much better equipped with the analyzed capitals. Furthermore, the highest capital values were observed in large and medium-sized cities of regional importance. From the point of view of the analyzed issues, the most interesting is type 6. Despite the low values of economic, cultural, and social capital, it has a very well-developed symbolic capital. The festival activity is impressive, considering their unfavorable conditions.

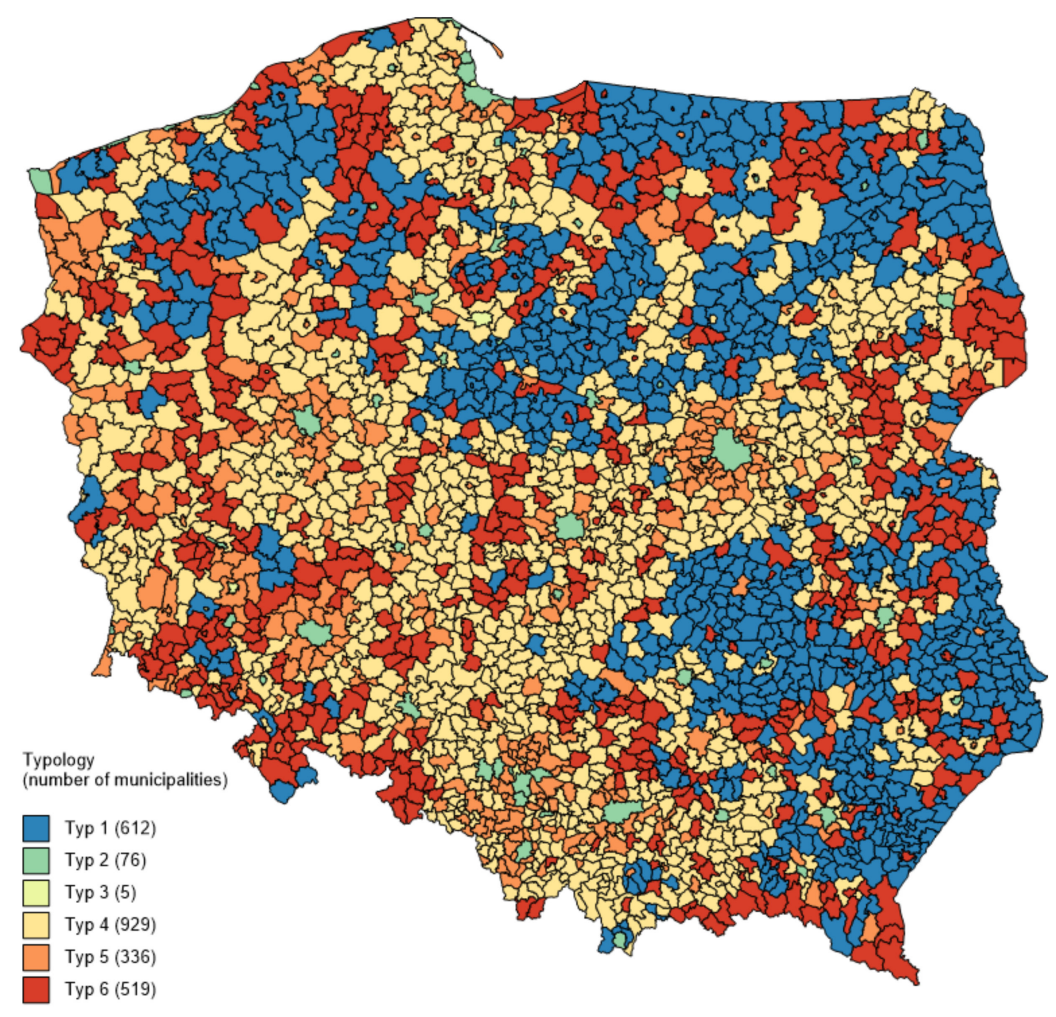

Figure 2. Typology of municipalities according to types of capital sustainability. Source: Author's own elaboration. 


\subsection{Location of Food Festivals and the Sustainability of Capital}

For the purposes of the study, an attempt to catalogue all food festivals in Poland was carried out. The process of collecting data on festivals and their locations was followed by a procedure that had already been used in similar studies [18]. In the first step, the resources of the Internet were used and we identified the largest possible number of food festivals in Poland by means of internet search engines and keywords. Then, we reviewed the websites of local municipalities, organizations, and social networks related to festivals. Additionally, the research was supplemented, in some cases, by phone calls and e-mail inquiries. In total, 64 food festivals were identified. In Figure 3, the bar graph shows both those that arose in a given year and those that take place cyclically, while the line chart shows only newly created events. The collected data present all identifiable festivals according to the adopted criteria (thematic, of a supra-specific range, determining the economic effect). Research shows that most of the food festivals were created between 2007 and 2010. Then, the dynamics of their formation clearly weakened. According to the adopted criteria, no new food festivals could be identified after 2016. Some identified examples of the oldest festivals in Poland after the Second World War are the "Święto Kwitnącej Jabłoni" (Festival of Blooming Apple Tree) in Łack in Małopolskie voivodeship and the "Winobranie" (Grape picking) festival in Zielona Góra in Lubuskie voivodeship. Food festivals are organized in different regions and on different times (Table 3 and Figure 4). The period of the highest festival activity are mainly the summer months: June, July, August, September. This is mainly conditioned by weather and the plant vegetation calendar in Poland. Thanks to this, festival participants can discover local flavors and agricultural products of the highest quality and freshness. Food and food events are grouped into three categories-festivals, holidays, and fairs. Festivals are a series of events, usually of one type, which are an overview of achievements in a given field, organized at one time and under a common name, often in the form of a competition. A food holiday, on the other hand, has definitely a local character and focuses on the presentation of local food products, historical reenactment, and discussion of local history related to agricultural and culinary traditions. The holiday has a specified theme and refers to a single local product, e.g., cherry, potato festival, or cheese holidays. As part of the holiday, all these elements will reactivate tradition, refresh memory, and introduce a festive character to the calendar of local events. A food fair is a large event related to the exhibition of international or national food products, combined with sales.

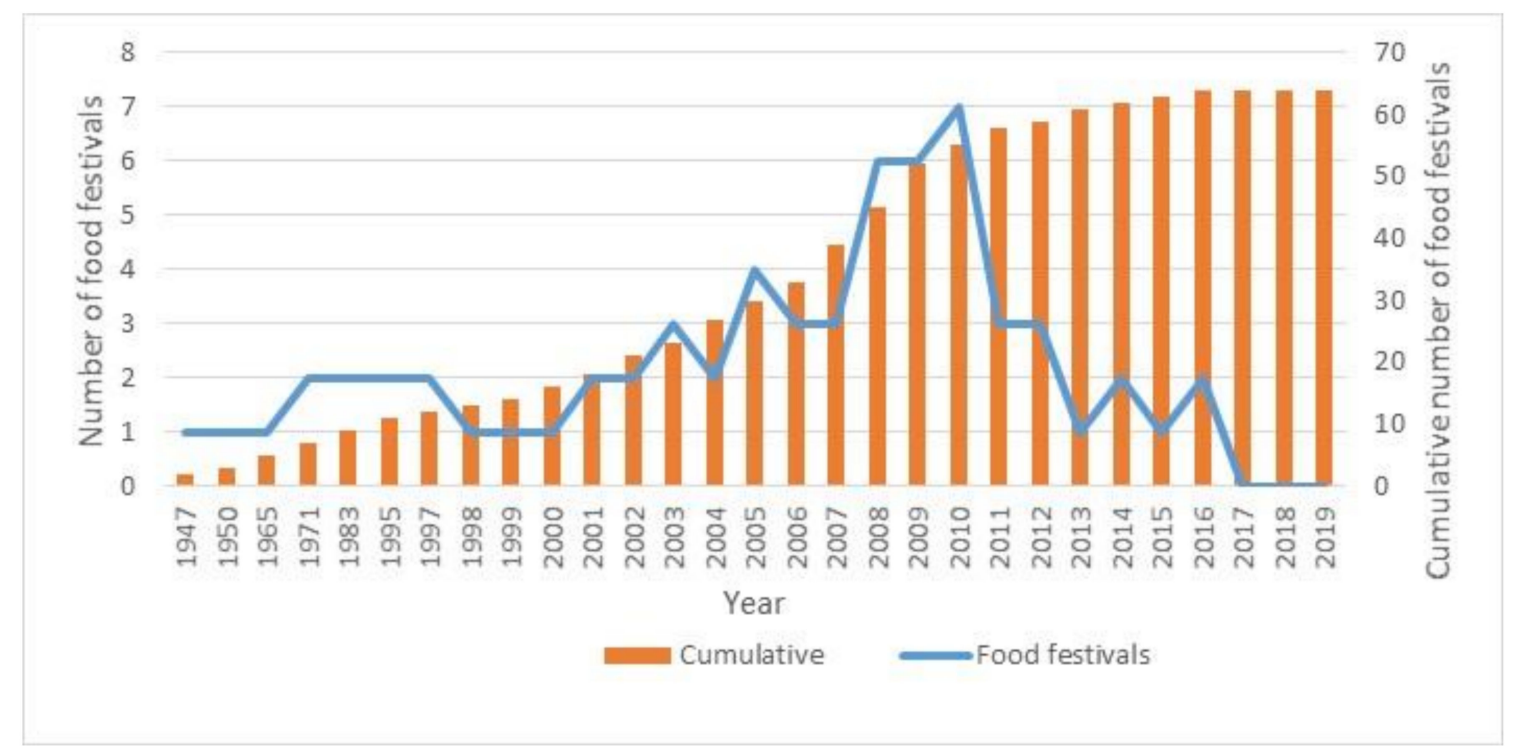

Figure 3. Development of food festivals in Poland in the years 1947-2019. Source: Authors' own elaboration. 
Table 3. Features of the location of food festivals in Poland by regions.

\begin{tabular}{|c|c|c|c|c|c|c|c|c|}
\hline \multirow{2}{*}{ Regions/Location } & \multicolumn{3}{|c|}{ Type of Food Event } & \multicolumn{3}{|c|}{ Type of Municipality } & \multirow{2}{*}{ Total } & \multirow{2}{*}{$\begin{array}{c}\begin{array}{c}\text { Agrarian } \\
\text { Fragmentation * }\end{array} \\
\text { Ha per Farm }\end{array}$} \\
\hline & Festivals & Holidays & Fairs & Urban & Urban-Rural & Rural & & \\
\hline Dolnośląskie & 4 & 2 & - & 3 & 1 & 2 & 6 & 16.46 \\
\hline Kujawsko-pomorskie & 3 & 1 & - & 1 & 2 & 1 & 4 & 15.77 \\
\hline Lubelskie & 3 & 3 & - & 3 & 2 & 1 & 6 & 7.73 \\
\hline Lubuskie & - & 2 & - & 2 & - & - & 2 & 21.18 \\
\hline Łódzkie & 1 & - & 1 & 1 & 1 & - & 2 & 7.72 \\
\hline Małopolskie & 2 & 5 & 1 & 2 & 3 & 3 & 8 & 4.04 \\
\hline Mazowieckie & 3 & 2 & 3 & 5 & - & 3 & 8 & 8.57 \\
\hline Podkarpackie & 4 & 3 & 1 & 2 & 2 & 4 & 8 & 4.77 \\
\hline Podlaskie & 1 & 2 & - & 1 & 1 & 1 & 3 & 12.27 \\
\hline Pomorskie & - & 2 & - & 1 & - & 1 & 2 & 19.16 \\
\hline Śląskie & 4 & 3 & - & 3 & 3 & 1 & 7 & 7.7 \\
\hline Świętokrzyskie & 1 & - & 1 & 2 & - & - & 2 & 5.67 \\
\hline Warmińsko-mazurskie & - & 1 & - & - & 1 & - & 1 & 22.79 \\
\hline Wielkopolskie & 1 & - & 1 & 2 & - & - & 2 & 13.56 \\
\hline Zachodniopomorskie & - & 3 & - & - & 1 & 2 & 3 & 30.35 \\
\hline Total & 27 & 29 & 8 & 28 & 17 & 19 & 64 & \\
\hline
\end{tabular}

* Average size of agricultural farms in ha in 2017, Agency for Restructuring and Modernization of Agriculture in Poland, Source: Author's own elaboration on the basis of data of The Agency for Restructuring and Modernization of Agriculture in Poland and The Main Office of Geodesy and Cartography.

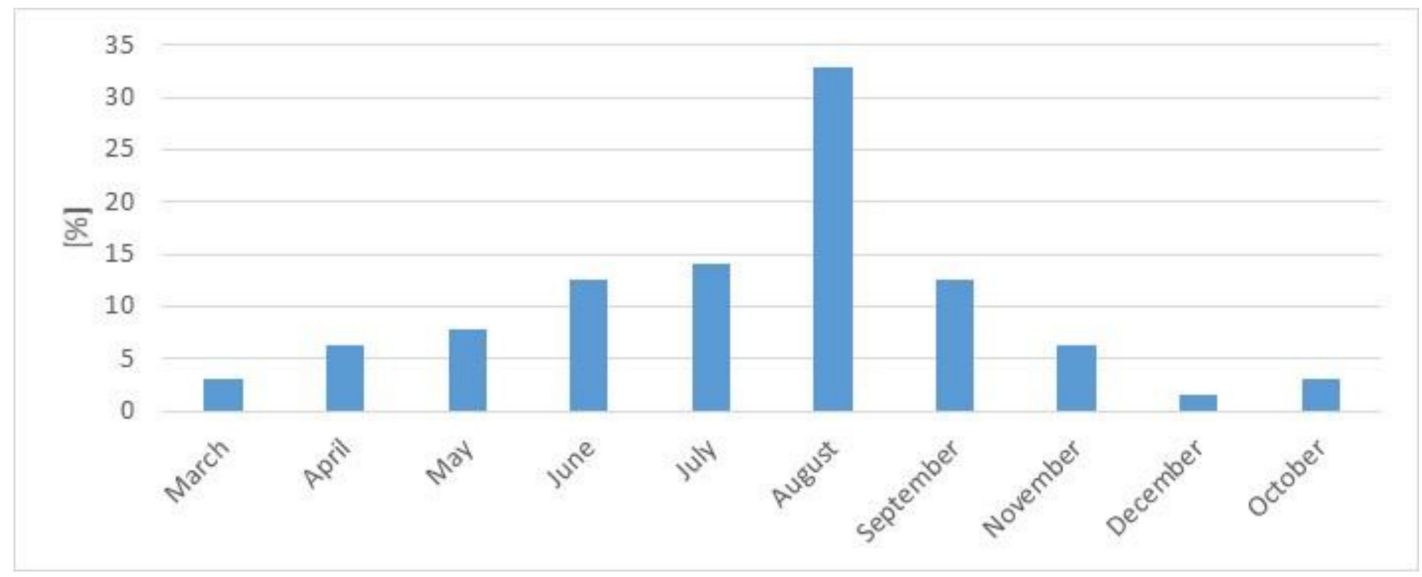

Figure 4. The time structure of food festivals organized in Poland in 2019. Source: Authors' own elaboration.

One of the reasons for the slow pace of changes in rural areas in Poland is the regional diversification of the area and number of farms (Table 3). In some voivodeships, the average size of farms is quite large, while in others, it is significantly smaller. In 2017, the smallest average farm area was in the following voivodeships: Małopolskie (4.04 ha), Podkarpackie (4.44 ha), Świętokrzyskie (5.67 ha), Śląskie (7.7 ha), and Mazowieckie (8.57 ha). Whereas, the largest area was recorded in the following voivodeships: Zachodniopomorskie (30.35 ha), Warmińsko-Mazurskie (22.79 ha), Lubuskie (21.18 ha), and Pomorskie (19.16 ha). In voivodeships with a low average, entities with a small acreage of agricultural land, and therefore economically weaker, are definitely dominant. As a consequence, in regions with greater fragmentation, a festival is a great opportunity to improve their situation and participate in the policy of food sovereignty and the production of traditional local food. This is reflected in the location of festivals in Poland (Figure 5). Most festivals take place in the following voivodeships: Małopolskie (8), Mazowieckie (8), Podkarpackie (8), and Ślaskie (7) (Table 3). These are the oldest regions in Poland with a rich historical and cultural tradition. They are the cradle of Polish culture and statehood. At the same time, as it was emphasized before, these are voivodeships with the greatest agrarian fragmentation and the number of farms. Each of these regions has its own specificity of food production and culinary traditions. Małopolska cuisine includes mutton dishes, trout, and sauerkraut soup that can be found in the entire region. Potato dishes such as pyzy ślaskie (Silesian dumplings) are extremely popular 
in Ślaska cuisine. In Śląsk, meat dishes are also very popular, with the most famous being golonka (pork hock). Cuisine from Mazowsze is mainly fruits and food found in the forest, such as mushrooms, berries, honey, blueberries, as well as game and poultry. The cuisine of Mazowsze also includes vegetables and various types of groats.

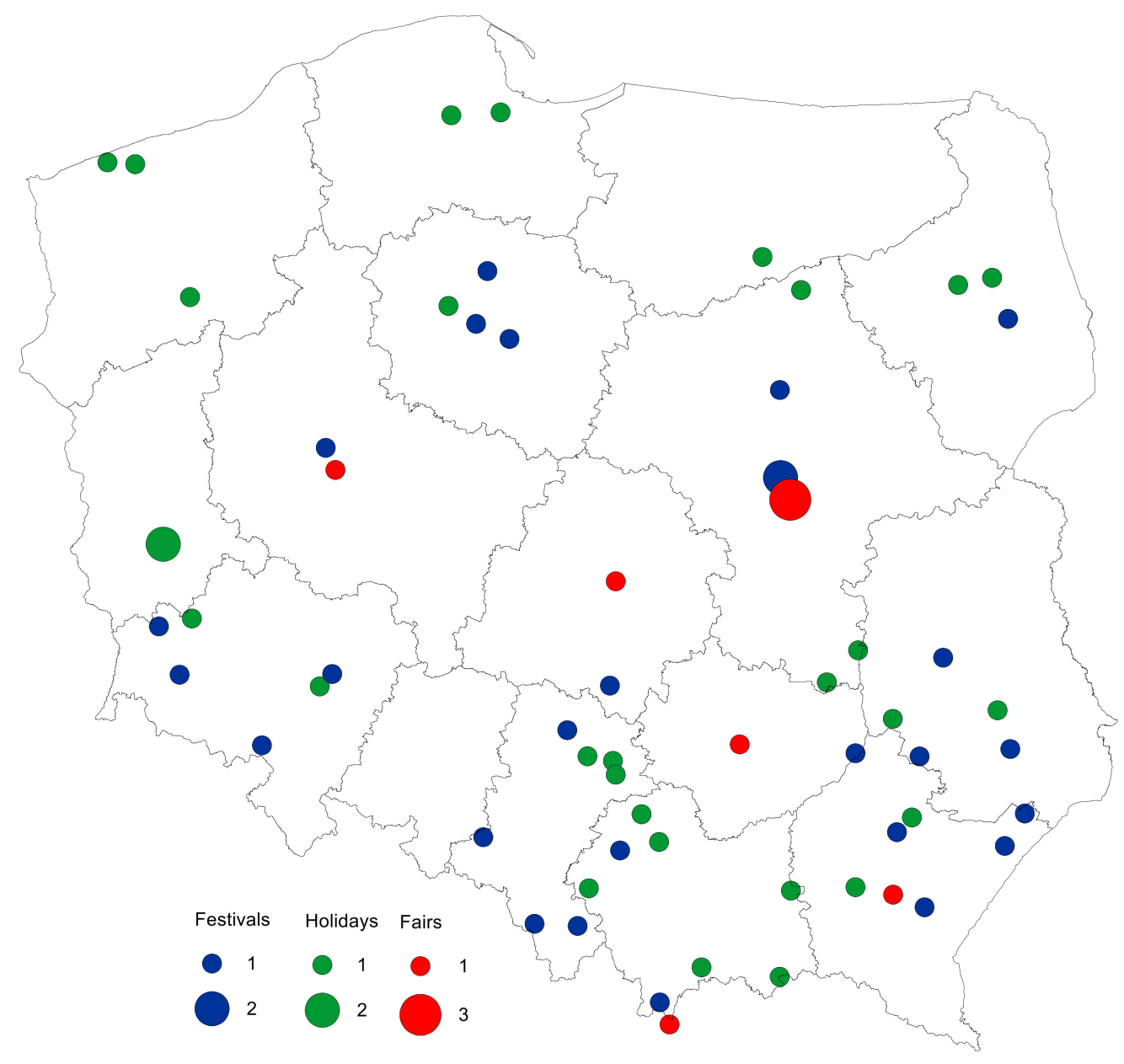

Figure 5. Mapping of food festivals in Poland. Source: Author's own elaboration.

\section{Discussion and Final Conclusions}

\subsection{Conclusions}

The analyses we have conducted allow us to conclude that the spatial concentration of food festivals is held mainly in large cities and their neighboring municipalities rather than in peripheral rural areas. Festivals are located in the vicinity of large urban centers, because these are areas characterized by high capital values-primarily economic capital, which determines the level of other capital. Inhabitants of large urban centers are often recipients of festivals organized in other municipalities, including rural ones [16,27].

We indicate that the urban areas have a higher level of capitals and sustainability of capitals for food festivals than rural areas. However, in our opinion, the sustainability of all capitals is conducive to the creation of festivals in a given location, but is not a key factor. Festivals are held in all types of municipalities with different capital structures (see types 1, 4, and 5 in Table 4). However, our theoretical considerations indicate that not all festivals generate the full effect that can be achieved with the full sustainability of capitals, especially symbolic and tourism. Only some festivals are able to contribute to the full circular effect and the conversion of economic capital, which can be re-engaged in the next cycle and can strengthen attachment to the location. Depending on the level and sustainability of 
capital, various economic effects are obtained. In some festivals, it has been observed that they are organized despite the average level of capital. In this case, it is determined by exogenous factors and external subsidies [16].

The model analysis also showed that the economic effect of festivals is stronger in locations with high tourism capital. An additional economic effect depends on the structure of the local economy and its provision with accommodation and service facilities [30]. Festival visitors not only use festival attractions, but also other services. In this way, they provide the local economy with additional income. This is visible in the second and third type municipalities, where the level of capital is sustainable and converted. It should be emphasized that various types of food events, to a large extent, motivate to visit a given tourist destination and make tourists' stay there more attractive. Type 2 and 3 of municipalities are units with a well-developed tourist infrastructure (e.g., restaurants, accommodation, and other tourist facilities). This is reflected in the capital levels. These areas have a high tourist potential with a high level of symbolic and economic capital at the same time. In turn, in type 6 municipalities, high values of symbolic capital do not convert into economic capital. It is caused by the low level of tourist capital in this type of municipalities.

Table 4. Features of the location of food festivals in Poland by regions.

\begin{tabular}{|c|c|c|}
\hline Type & Characteristic Municipalities & Location of Food Festivals * \\
\hline 1 & 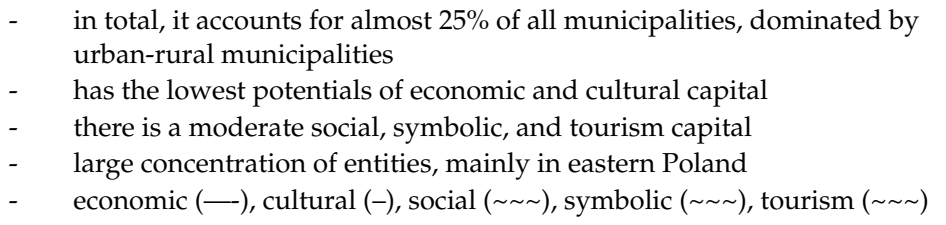 & $\begin{array}{l}\text { Lipsko(u-r), Myszyniec(u-r), } \\
\text { Narol(u-r), Krzeszów(r), } \\
\text { Dubiecko(r), Sokołów } \\
\text { Małopolski(u-r), Lelów(r) }\end{array}$ \\
\hline 2 & 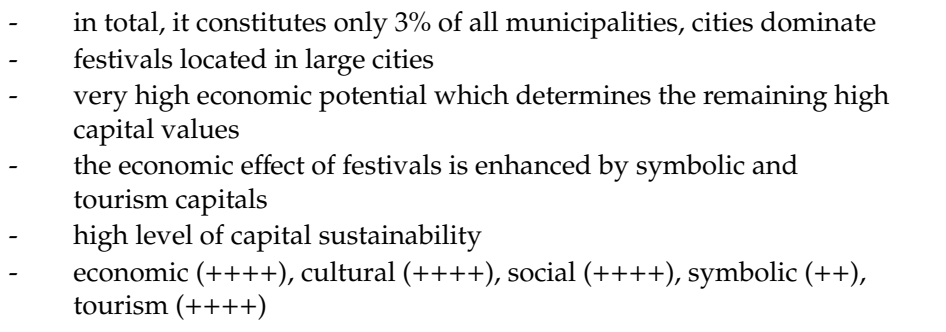 & $\begin{array}{l}\text { Wrocław }(u), \text { Lublin }(u), \text { Łódź(u), } \\
\text { Zakopane(u), Warszawa }(u) \\
\text { Rzeszów }(u), \text { Białystok }(u) \\
\text { Gdańsk(u), Kielce(u), Poznań(u), } \\
\text { Rewal(r) }\end{array}$ \\
\hline 3 & $\begin{array}{l}\text { - } \quad \text { the smallest, only } 5 \text { municipalities, } \\
\text { - } \quad \text { very high values of all capitals, } \\
\text { - } \quad \text { hub-regional centers, } \\
\text { - } \quad \text { high economic potential, which determines the high values of other } \\
\text { types of capital, primarily social (network) capital } \\
\text { - } \quad \text { very high level of capital sustainability } \\
\text { - } \quad \text { conomic }(++++), \text { cultural }(++++), \text { social }(++++), \text { symbolic }(++++), \\
\text { tourism }(++++)\end{array}$ & Toruń(u) \\
\hline 4 & 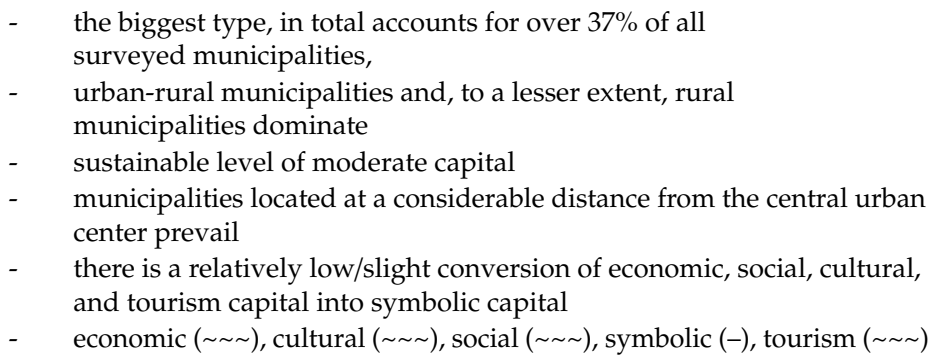 & $\begin{array}{l}\text { Dobrcz(r), Zławieś Wielka(r), } \\
\text { Zamość(r), Radomsko(r), } \\
\text { Krzeszowice(u-r), Słomniki(u-r), } \\
\text { Charsznica(r), Łacko(r), Zator(u-r), } \\
\text { Pilzno(u-r), Mońki(u-r), Irządze(r), } \\
\text { Szczytno(r), Trzebiatów(u-r) }\end{array}$ \\
\hline
\end{tabular}


Table 4. Cont.

\begin{tabular}{|c|c|c|}
\hline Type & Characteristic Municipalities & Location of Food Festivals * \\
\hline 5 & $\begin{array}{l}\text { - } \quad \text { accounts for over } 13 \% \text { of all municipalities } \\
\text { there is a balanced structure of the number of municipalities, i.e., a } \\
\text { similar number of cities, rural municipalities, } \\
\text { and urban-rural municipalities } \\
\text { includes entities located in the immediate vicinity of large cities, located } \\
\text { in central and southwest Poland } \\
\text { - } \quad \text { high level of economic and cultural capital } \\
\text { - } \quad \text { moderate level of other types of capital } \\
\text { - } \quad \text { occur mainly around large cities } \\
\text { - } \quad \begin{array}{l}\text { economic }(++++), \text { cultural }(++++), \text { social }(\sim \sim \sim), \text { symbolic }(\sim \sim), \\
\text { tourism }(\sim \sim)\end{array}\end{array}$ & $\begin{array}{l}\text { Osiecznica(r), Świecie(u-r), } \\
\text { Zielona Góra(u), Boguchwała(u-r), } \\
\text { Korycin(r), Kartuzy(u-r), } \\
\text { Ustroń(u), Kuźnia Raciborska(u-r), } \\
\text { Żywiec(u), Częstochowa(u), } \\
\text { Sandomierz(u) }\end{array}$ \\
\hline 6 & $\begin{array}{ll}\text { - } & \text { in total, accounts for } 21 \% \text { of all municipalities, dominated by } \\
\text { - } & \text { modban-rural and rural municipalities } \\
\text { - } & \text { high level of symbolic capital } \\
\text { - } & \text { large spatial dispersion mainly in the border zone } \\
\text { - } & \text { economic }(\sim \sim \sim) \text {, cultural }(\sim \sim) \text {, social }(\sim \sim) \text {, symbolic }(++++) \text {, tourism } \\
& (\sim \sim)\end{array}$ & $\begin{array}{l}\text { Lwówek Śląski(u-r), } \\
\text { Przemków(u-r), Jedlina-Zdrój(u), } \\
\text { Janów Lubelski(u-r), } \\
\text { Krasnystaw(u), Kraśnik(u), } \\
\text { Janowiec(r), Uście Gorlickie(r), } \\
\text { Pułtusk(u-r), Lubaczów(u), } \\
\text { Janów(r), Kalisz Pomorski(u-r) }\end{array}$ \\
\hline
\end{tabular}

One more conclusion emerges from our observations. The dispersed agrarian structure helps to preserve the tradition of local food production and the location of festivals. This is especially visible in southern and southeastern Poland, where the level of agrarian fragmentation is high, and where the locations of numerous food festivals have been identified. These are areas with a low level of economic and cultural capital, but the identified level of social capital, and most importantly, the level of symbolic and tourist capital, is relatively high. They are essential for effective operation in the field of both economy and politics. They testify to the strong embeddedness of the elements of culture and heritage that are used to organize food festivals. Small family farms, strongly rooted in the local environment with traditional farming methods, favor the preservation and use of culinary heritage, which is a very important element of food tourism and may stimulate the development of agro-tourism [68]. The interest of tourists in local, regional, and traditional food products, and above all, in typical dishes and the methods of their production, has a direct impact on the development of food tourism and the location of culinary festivals there. Furthermore, what is authentic in the culinary heritage, production, preparation, or tasting of products and dishes of a given region contributes to the development of sustainable food tourism [58]. It should be also noted that devoid of symbolic capital social, cultural and economic resources turn out to be of extremely little value.

In our study, we verified the following hypotheses (Table 5):

Table 5. Hypothesis support.

\begin{tabular}{llc}
\hline \multicolumn{1}{c}{ Hypothesis } & \multicolumn{1}{c}{ Verification Methods } & Support \\
\hline $\begin{array}{l}\text { H1. Food festivals are held mainly in large } \\
\text { cities and their neighboring municipalities } \\
\text { rather than in peripheral rural areas. }\end{array}$ & $\begin{array}{l}\text { Mapping and analysis of a food festival's } \\
\text { locations using geographic information } \\
\text { systems (GIS) }\end{array}$ & Yes \\
\hline $\begin{array}{l}\text { H2. Urban areas have a higher level of } \\
\begin{array}{l}\text { capitals and sustainability of capitals of } \\
\text { food festivals than rural areas. }\end{array}\end{array}$ & $\begin{array}{l}\text { Assessment of the sustainability of the } \\
\text { indicator structure (k-means classification) }\end{array}$ & Yes \\
$\begin{array}{l}\text { H3. The impact of food festivals on capitals } \\
\begin{array}{l}\text { conversion is stronger if there is a high } \\
\text { tourism capital in the local environment. }\end{array}\end{array}$ & $\begin{array}{l}\text { Assessment of the sustainability of the } \\
\text { indicator structure (k-means classification) }\end{array}$ & Yes \\
\hline
\end{tabular}


The results of our research are in line with the academic discussion on the importance of festivals in both economic and social context. In the scientific literature, they are generally analyzed by their significant importance for the quality of life and for local identity $[17,18]$. Researchers also emphasize significance of heritage in the organization of festivals but seldom address the effect of festival as a potent force that contributes to place making $[69,70]$. Some see the impact of food festivals through the prism of importance not only for the tourism sector and sustainable positioning of the destination, but also through the prism of its relevance for the local economy due to the consumption of local food products [71]. However, in our opinion, Polish and foreign scientific literature in the field of food tourism lacks research that covers the connections between the location of food festivals with the theory of capitals and their sustainability, and the embeddedness concept. Therefore, to fill this gap, this research is one of the first attempts to understand the relationship between the location of food festivals and the sustainability of locally embedded capitals. From the theoretical point of view, the study shows that sustainable development of rural areas based on the food festival requires a neo-endogenic approach to development planning. This means that economic, cultural, social, symbolic, and tourism capitals must be available in a given festival location. In the absence of economic capital, it may come from outside the location. External factors may also include assistance in the organization and financing of local events. Furthermore, it was noticed that the promoted in Poland new model of large-scale agriculture, on the one hand, improves the economic conditions and profitability of agricultural production, whereas on the other, it does not strengthen the spirit of rural tradition and culture. Global food systems are causing local and regional cuisine to be modified and often forgotten. Paradoxically, high agrarian fragmentation, considered to be a factor delaying the development of rural areas, supports the spirit of tradition and ruralism, including cultural identity and local food traditions.

\subsection{Practical Implications}

The search for an effective sustainable consumption strategy is currently the goal of many countries and organizations around the world. Practical solutions aimed at changes in the behavior of demand and improvement of commonly present bad eating habits are introduced. Created food systems more and more often use local food and agricultural production [4,5]. This not only affects the local economy, but also shortens supply chains, reduces fuel consumption concerning food transport, and improves the environment. Promoting sustainable food systems through food festivals and food tourism can prove to be an effective strategy for introducing change.

In the coming years, food tourism will probably gain more and more popularity among people interested in gastronomy, i.e., culture and culinary art, as well as catering services [71]. Poland, due to its diverse and different regional cuisines, is a great tourist attraction for both domestic and foreign tourists. The uniqueness and originality of Polish cuisine make all regions in Poland develop the already existing cultural attractions, and above all, create new ones that affect new sensations and experiences related to the desire to practice food tourism in all its forms. Our analyses show that food events as a form of popularization of regional, local, and traditional food, are located primarily in certain specific areas. The organization of food festivals can simultaneously use the existing capital and influence their level. In this way, it contributes to the development of a given entity, and by promoting locally produced, authentic products of recognized quality, it helps implement the principles of sustainable development [52]. Food festivals that are organized locally and use local resources are becoming a tool for implementing global changes, e.g., those that concern sustainable consumption, sustainable development and local food systems, and food sovereignty. In this way, they implement the idea of "think globally, act locally".

\subsection{Limitation and Future Research Directions}

The presented research helps to better understand the importance of food festivals for sustainable development in the context of various capitals rooted in the local environment. However, it presents 
several limitations, which at the same time constitute a challenge for planning future research in the field of food festivals. First, although the scale and structure of capital for festival locations has been developed and tested, understanding the mechanisms of capital conversion requires further research and in-depth interviews among local communities. This study was limited to food festivals, thus future research should focus on collecting data on different festivals and different destination types to further test the combined effects of festivals on conversion processes and attachment to place through capital. Second, this study did not concern different social structures for location, and therefore did not include other cultural structures arising, for example, from gentrification processes in rural areas. Third, future research can take into account the cultural diversity of festivals and ways to manifest this culture through culinary products and building social relationships. Fourth, while this study empirically tested the relationships between the level and structure of capitals and the location of food festivals, others may take into account different variables (e.g., festival landscape, festival quality, and festival experience) to further confirm the causal relationships between locally embedded capitals and sustainable development. Summing up, we hope that our research will contribute to further discussion about the processes related to the location of food festivals.

Author Contributions: Conceptualization, P.Z.; methodology, P.Z.; software, P.Z. and D.Z.-G.; analysis, P.Z. and D.Z.-G.; investigation, P.Z. and D.Z.-G.; resources, P.Z. and D.Z.-G.; writing-original draft preparation, P.Z. and D.Z.-G.; writing-review and editing, P.Z. and D.Z.-G.; visualization, P.Z. and D.Z.-G. All authors have read and agreed to the published version of the manuscript.

Funding: This research was funded by National Science Center in Poland grant number 2019/33/B/HS4/02068 And The APC was funded by National Science Center in Poland grant number 2019/33/B/HS4/02068.

Conflicts of Interest: The authors declare no conflict of interest.

\section{References}

1. Smith, P.; Martino, D.; Cai, Z.; Gwary, D.; Janzen, H.; Kumar, P.; McCarl, B.; Ogle, S.; O’Mara, F.; Rice, C.; et al. Agriculture. In Climate Change; Cambridge University Press: Cambridge, UK, 2007; pp. 497-540.

2. Alexandratos, N. (Ed.) World Agriculture: Towards 2030/50, Interim Report; An FAO Perspective; Earthscan: London, UK; FAO: Rome, Italy, 2006.

3. Ziegler, J. Betting on Famine: Why the World Still Goes Hungry, 2nd ed.; New Press: New York, NY, USA; London, UK, 2013; pp. 150-163.

4. Moschis, G.P.; Mathur, A.; Shannon, R. Toward Achieving Sustainable Food Consumption: Insights from the Life Course Paradigm. Sustainability 2020, 12, 5359. [CrossRef]

5. Hall, C.M.; Gössling, S. (Eds.) Sustainable Culinary Systems: Local Foods, Innovation, and Tourism E Hospitality; Routledge: Auckland, New Zealand, 2013; pp. 3-42.

6. Haynes, N. Food Fairs and Festivals. In The SAGE Encyclopedia of Food Issues, 1st ed.; Albala, K., Ed.; SAGE Publication: Thousand Oaks, CA, USA, 2015; pp. 565-569.

7. Jęczmyk, A.; Kasprzak, K. Culinary tourism in Poland in the light of the sustainable development concept. Pol. J. Sustain. Dev. 2017, 21, 7-14. (In Polish) [CrossRef]

8. Jong, A.; Varley, P. Food tourism and events as tools for social sustainability? J. Place Manag. Dev. 2018, 11, 277-295. [CrossRef]

9. Fontefrancesco, M. Food Festivals and Expectations of Local Development in Northern Italy. Ethnol. Actual. 2019, 18, 118-134. [CrossRef]

10. Litvin, S.; Fetter, E. Can a festival be too successful? A review of Spoleto, USA. Int. J. Contemp. Hosp. Manag. 2006, 18, 41-49. [CrossRef]

11. Hall, S. Hallmark Tourist Events: Impacts, Management and Planning; Belhaven Press: London, UK, 1992; pp. 56-72.

12. Getz, D. Event tourism: Definition, evolution and research. Tour. Manag. 2008, 29, 403-428. [CrossRef]

13. Balaguer, J.; Cantavella-Jordá, M. Tourism as a long-run economic growth factor: The Spanish case. Appl. Econ. 2002, 34, 877-884. [CrossRef]

14. Laing, J. Festival and event tourism research: Current and future perspectives. Tour. Manag. Perspect. 2018, 25, 165-168. [CrossRef] 
15. Lee, W.; Sung, H.; Suh, E.; Zhao, J. The effects of festival attendees' experiential values and satisfaction on re-visit intention to the destination: The case of a food and wine festival. Int. J. Contemp. Hosp. Manag. 2017, 29, 1005-1027. [CrossRef]

16. Tohmo, T. Economic impacts of cultural events on local economics: An input-output analysis of the Kaustinen Folk Music. Tour. Econ. 2005, 11, 431-451. [CrossRef]

17. Hjalager, A.-M.; Kwiatkowski, G.; Larsen, M.Ø. Innovation gaps in Scandinavian rural tourism. Scand. J. Hosp. Tour. 2017, 18, 1-17. [CrossRef]

18. Hjalager, A.M.; Kwiatkowski, G. Entrepreneurial implications, prospects and dilemmas in rural festivals. J. Rural Stud. 2018, 63, 217-228. [CrossRef]

19. Backman, K. Event management research: The focus today and in the future. Tour. Manag. Perspect. 2018, 25, 169-171. [CrossRef]

20. Brännäs, K.; Hellström, J.; Nordström, J. A new approach to modelling and forecasting monthly guest nights in hotels. Int. J. Forecast. 2002, 18, 19-30. [CrossRef]

21. Kwiatkowski, G.; Oklevik, O.; Hjalager, A.; Maristuen, H. The assemblers of rural festivals: Organizers, visitors and locals. Eur. Plan. Stud. 2020, 28, 255-272. [CrossRef]

22. Rifkin, J.; Swanson, T.M.; Barbier, E.B.; Holmberg, J.; Wibe, S.; Jones, T.; Mcgehee, W.; Thayer, P.W.; Echenique Larrain, J.; Villavicencio Rivera, M.; et al. Beyond Beef: The Rise and Fall of the Cattle Culture; Banco Mundial: Washington, DC, USA, 1992.

23. Shin, Y. Tourism Development in North Korea: Economical and Geopolitical Perspective. Anatolia 2004, 15, 150-163. [CrossRef]

24. Shin, H. Cultural festivals and regional identities in South Korea. Environ. Plan. D Soc. Space 2004, 22, 619-632. [CrossRef]

25. Bourdieu, P. The forms of capital. In Handbook of Theory and Research for the Sociology of Education, 1st ed.; Richardson, J., Ed.; Westport: Greenwood, IN, USA, 1986; pp. 241-258.

26. Granovetter, M. Economic Action and Social Structure: The Problem of Embeddedness. Am. J. Sociol. 1985, 91, 481-510. [CrossRef]

27. Carlsen, J.; Anderson, T.; Ali-Knight, J.; Jaeger, K.; Taylor, R. Festival management innovation and failure. Int. J. Event Festiv. Manag. 2010, 1, 120-131. [CrossRef]

28. Smith, S.; Xiao, H. Culinary tourism supply chains: A preliminary examination. J. Travel Res. 2008, 46, $289-299$. [CrossRef]

29. Veenstra, G. Social space, social class and Bourdieu: Health inequalities in British Columbia, Canada. Health Place 2007, 13, 14-31. [CrossRef] [PubMed]

30. Zarębski, P.; Kwiatkowski, G.; Malchrowicz-Mośko, E.; Oklevik, O. Tourism Investment Gaps in Poland. Sustainability 2019, 11, 6188. [CrossRef]

31. Han, Z.; Schefold, B. An empirical investigation of paradoxes: Reswitching and reverse capital deepening in capital theory. Camb. J. Econ. 2006, 30, 737-765. [CrossRef]

32. Harriss, J. Social Capital Construction and the Consolidation of Civil Society in Rural Areas; Development Studies Institute (DESTIN) Working Paper 00-16; London School of Economics: London, UK, 2001; ISSN 1470-2320.

33. Pasinetti, L.; Scazzieri, R. Capital theory (paradoxes). In The New Palgrave Dictionary of Economics, 1st ed.; Eatwell, J., Durlauf, S.N., Blume, L., Eds.; Palgrave Macmillan: London, UK, 1990; pp. 136-147.

34. Storberg, J. The Evolution of Capital Theory: A Critique of a Theory of Social Capital and Implications for HRD. Hum. Resour. Dev. Rev. 2002, 1, 468-499. [CrossRef]

35. Bourdieu, P. Social Space and Symbolic Power. Sociol. Theory 1989, 7, 14-25. [CrossRef]

36. Coleman, J. Social Capital in the Creation of Human Capital. Am. J. Sociol. 1988, 94, 95-120. [CrossRef]

37. Putnam, R. The prosperous community: Social capital and public life. Am. Prospect 1993, 13, $35-42$.

38. Fukuyama, F. Social Capital and the Global Economy. Foreign Aff. 1995, 75, 89-103. [CrossRef]

39. Bourdieu, P.; Passeron, J.C. Theory, culture E society. Reproduction in Education, Society and Culture, 2nd ed.; Sage: London, UK, 1990.

40. Pret, T.; Shaw, E.; Drakopoulou Dodd, S. Painting the full picture: The conversion of economic, cultural, social and symbolic capital. Int. Small Bus. J. 2016, 34, 1004-1027. [CrossRef]

41. Godlewska-Majkowska, H. Atrakcyjność Inwestycyjna Polskich Regionów: W Poszukiwaniu Nowych Miar; Wydawnictwo Szkoły Głównej Handlowej: Warszawa, Poland, 2008. (In Polish) 
42. Middleton, V. Tourist product. In Tourism Marketing and Management Handbook; Witt, F.S., Moutinho, L., Eds.; Prentice Hall: London, UK, 1989.

43. Gartner, W. Tourism image: Attribute measurement of state tourism products using multidimensional scaling techniques. J. Travel Res. 1989, 28, 16-20. [CrossRef]

44. Meinung, A. Determinants of the attractiveness of tourism region. In Tourism Marketing and Management Handbook; Witt, F.S., Moutinho, L., Eds.; Prentice Hall: Hertfordshire, UK, 1995.

45. Kim, H.B. Perceived attractiveness of Korean destinations. Ann. Tour. Res. 1998, 25, 340-361.

46. Malchrowicz-Mośko, E.; Poczta, J. A small-scale event and a big impact-Is this relationship possible in the world of sport? The meaning of heritage sporting events for sustainable development of tourism-Experiences from Poland. Sustainability 2018, 10, 4289. [CrossRef]

47. Gołembski, G. Wyodrębnianie regionów turystycznych. In Kompendium Wiedzy o Turystyce; Gołembski, G., Ed.; Wydawnictwo Naukowe PWN: Warsaw, Poland, 2002. (In Polish)

48. Granovetter, M. The Impact of Social Structure on Economic Outcomes. J. Econ. Perspect. 2005, 19, 33-50. [CrossRef]

49. Swedberg, R. New Economic Sociology: What Has Been Accomplished, What Is Ahead? Acta Sociol. 1997, 40, 161-182. [CrossRef]

50. Granovetter, M. Economic Institutions as Social Constructions: A Framework for Analysis. Acta Sociol. 1992, 35, 3-11. [CrossRef]

51. Granovetter, M.; Swedberg, R. The Sociology of Economic Life, 2nd ed.; Westview Press: Boulder, CO, USA, 2011.

52. Zelizer, B. Journalism, Memory, and the Voice of the Visual. In About to Die: How News Images Move the Public; Zelizer, B., Ed.; Oxford University Press: Oxford, UK, 2010.

53. Polanyi, K. The Political and Economic Origins of Our Time; Beacon Press: Boston, MA, USA, 2001.

54. Halfacree, K. Rural space: Constructing a three-fold architecture. In Handbook of Rural Studies; Cloke, P., Marsden, T., Mooney, P., Eds.; Sage Publishing: Thousand Oaks, CA, USA, 2006.

55. Edelman, M. Food Sovereignty: Forgotten Genealogies and Future Regulatory Challenges. J. Peasant Stud. 2014, 41, 959-978. [CrossRef]

56. Shattuck, A.; Schiavone, C.; VanGelder, Z. Translating the Politics of Food Sovereignty: Digging into Contradictions, Uncovering New Dimensions. Globalizations 2015, 12, 421-433. [CrossRef]

57. Pingali, P.; Aiyar, A.; Abraham, M.; Rahman, A. Transforming Food Systems for a Rising India; Palgrave Macmillan: Cham, Switzerland, 2019; pp. 15-45.

58. Getz, D. Special events: Defining the product. Tour. Manag. 1989, 10, 135-137. [CrossRef]

59. Kukuła, K. Metoda unitaryzacji zerowanej na tle wybranych metod normowania cech diagnostycznych. Acta Sci. Acad. Ostroviensis 1999, 4, 5-31. (In Polish)

60. Borowicz, A.; Kostyra, M.; Dzierżanowski, M.; Szultka, S.; Wandałowski, M. Atrakcyjność Inwestycyjna Województw i Podregionów Polski 2016; Instytut Badań nad Gospodarką Rynkową: Gdańsk, Poland, 2016. (In Polish)

61. Jung, S.H.; Huh, J.H. A novel on transmission line tower big data analysis model using altered K-means and ADQL. Sustainability 2019, 11, 3499. [CrossRef]

62. Local Data Bank. Statistics Poland. Available online: https://bdl.stat.gov.pl (accessed on 12 August 2020).

63. Hartigan, J.A.; Wong, M.A.; Algorithm, A.S. A k-means clustering algorithm. J. R. Stat. Soc. Ser. C 1979, 28, 100-108.

64. Yao, Y.; Li, X.; Liu, X.; Liu, P.; Liang, Z.; Zhang, J.; Mai, K. Sensing spatial distribution of urban land use by integrating points-of-interest and Google Word2Vec model. Int. J. Geogr. Inf. Sci. 2017, 31, 825-848. [CrossRef]

65. Cheng, S.T.; Lee, C.K.; Chan, A.C.; Leung, E.M.; Lee, J.J. Social network types and subjective well-being in Chinese older adults. J. Gerontol. Ser. B: Psychol. Sci. Soc. Sci. 2009, 64, 713-722. [CrossRef] [PubMed]

66. Boonchai, P.; Freathy, P. Cross-border tourism and the regional economy: A typology of the ignored shopper. Curr. Issues Tour. 2020, 23, 626-640. [CrossRef]

67. Zegar, J. The issue of land concentration in Polish individual agriculture. Yearb. Agric. Sci. 2009, 96, $256-266$. (In Polish)

68. Gössling, S.; Ring, A.; Dwyer, L.; Andersson, A.C.; Hall, C.M. Optimizing or maximising? A challenge to sustainable tourism. J. Sustain. Tour. 2016, 24, 527-548. [CrossRef] 
69. Liu, C.; Lin, W.; Wang, Y.; Chen, S. Sustainability indicators for festival tourism: A multi-stakeholder perspective. J. Qual. Assur. Hosp. Tour. 2018, 20, 296-316. [CrossRef]

70. Lay, C.; Li, Y. Analyzing the effects of an urban food festival: A place theory approach. Ann. Tour. Res. 2019, 74, 43-55. [CrossRef]

71. Colgado-Fernández, J.; Di-Clemente, E.; Hernández-Mogollón, J. Food Festivals and the Development of Sustainable Destinations. The Case of the Cheese Fair in Trujillo (Spain). Sustainability 2019, 11, 2922. [CrossRef]

Publisher's Note: MDPI stays neutral with regard to jurisdictional claims in published maps and institutional affiliations.

(C) 2020 by the authors. Licensee MDPI, Basel, Switzerland. This article is an open access article distributed under the terms and conditions of the Creative Commons Attribution (CC BY) license (http://creativecommons.org/licenses/by/4.0/). 